\title{
Meta-Analysis of the Effect of Prenatal Stress on the Premature Birth
}

\author{
Irfa Nur Faujiah'), Bhisma Murti'), Hanung Prasetya2) \\ 1)Masters Program in Public Health, Universitas Sebelas Maret \\ ${ }^{2)}$ Study Program of Acupunture, School of Health Polytechnics, Ministry of Health, Surakarta
}

\section{ABSTRACT}

Background: Premature birth is a major global public health problem, especially in developing countries. One of the causes of this incident is exposure to psychological stress experienced during pregnancy. This study aims to estimate the magnitude of the effect of prenatal stress on preterm birth using a metaanalysis study.

Subjects and Method: The meta-analysis research was conducted by selecting articles published in the years 2006-2020, from the PubMed, Google Scholar, Science Direct, Directory of Open Access (DOAJ), and Springer Link databases. The article search was carried out by considering the eligibility criteria defined using the PICO model. The population in the study were pregnant women with high stress prenatal intervention, comparison with low stress and preterm birth outcomes. This article was collected for 1 month using the following keywords: "Prenatal Stress" AND "Preterm Birth". The inclusion criteria were a free full text study, using English and Indonesian, high stress pregnant women, observational studies, and the results were reported in the Adjusted Odds Ratio (aOR). The meta-analysis study was carried out with the Review Manager 5.3 program.

Results: Meta-analysis of 10 cohort studies showed that pregnant women with high stress were at risk for preterm birth (aOR $=1.35 ; 95 \%$ $\mathrm{CI}=1.05$ to $1.73 ; \mathrm{p}=0.02$ ), and 4 case-control studies showed that pregnant women with high stress had a risk for preterm birth $(\mathrm{aOR}=2.00$; $95 \% \mathrm{CI}=0.61$ to $6.50 ; \mathrm{p}=0.25$ ).

Conclusion: Prenatal stress has a risk of preterm birth.

Keywords: Pregnant women, prenatal stress, preterm birth, meta-analysis

\section{Correspondence:}

Irfa Nur Faujiah. Masters Program in Public Health. Universitas Sebelas Maret, Jl. Ir. Sutami 36A, Surakarta 57126, Jawa Tengah, Indonesia. Email: irfanurfaujiah@gmail.com. Mobile: +6282127200347 .

Cite this as:

Faujiah IN, Murti B, Prasetya H (2020). Meta-Analysis of the Effect of Prenatal Stress on the Premature Birth. J Matern Child Health. 05(06): 601-613. https://doi.org/10.26911/thejmch.2020.05.06.01.

cc) (1) $\$(0)$ Journal of Maternal and Child Health is licensed under a Creative Commons Journal of Maternal and Child Health is licensed under a Creative Cor
Attribution-NonCommercial-ShareAlike 4.o International License.

\section{BACKGROUND}

Preterm birth is a birth that occurs at $<37$ weeks of gestation and is still a major problem in the field of public health (Grobman et al., 2018).

Globally, in 2000 the rate of preterm birth was estimated at $9.8 \%$, then in 2014 it rose to around $10.6 \%$ (Tanpradit and Kaewkiattikun, 2020). In 2014, the highest rates of preterm birth were in Southeast Asia, South Asia, and sub-Saharan Africa.
Premature birth is caused by exposure to maternal psychological stress such as stress, anxiety, and depression (Khashan et al., 2014). Stress is defined as an individual's attitude to challenge the ability to overcome problems in any event which is the result of psycho-physiology (Shapiro et al., 2013). Stress can also be a threat or be considered a threat to the physiological balance of the individual and be associated 
with adverse outcomes. Maternal stress is a broad concept covering perceived stress, depressive symptoms, racial discrimination, stressful life events, and pregnancyspecific stress (Cardwell, 2017). According to the professional organization of obstetricians, the American College of Obstetricians and Gynecologists (ACOG) recognizes that the effects of stress experienced by pregnant women have an impact on both mother and baby (Cardwell, 2017).

The results showed that $27.2 \%$ of women experienced high levels of stress during the first two trimesters of pregnancy. Women who experienced high levels of stress during the first two trimesters were almost twice as likely to experience depression during the third trimester. The high level of stress that is felt during pregnancy is associated with the incidence of LBW, preterm birth, and low APGAR scores (Gokoel et al., 2020).

Based on the results of the study, it was stated that the population of mothers who experienced stress during pregnancy had a strong direct influence on the incidence of depression (Eick et al., 2020). In addition, preterm birth can have detrimental effects on the baby or child who is born such as: increased risk of cognitive deficits [low IQ score]; stunting; on average experienced worse physical health; stunted children's motor development and a spectrum of potential complications including social relationships and emotional problems; more likely to show a delay in expressive behavior and more likely to be temperamental; Dead; and the additional economic costs for families to care for premature babies (Glynn et al., 2008; Gokoel et al., 2020).

There have been many studies conducted to confirm the link between mental stress such as stress and negative birth outcomes such as preterm birth. However, the evidence that connects the two is still controversial, so it is not conclusive. Based on this, the impact of stress experienced by pregnant women requires proper handling, so the researchers are interested in examining the effect of stress experienced by pregnant women on preterm birth. The aim of this study was to estimate the influence of prenatal stress on preterm birth based on the results of a number of previous studies.

\section{SUBJECTS AND METHOD}

\section{Study Design}

This study was conducted using a systematic review study and meta-analysis. The articles in this study were obtained from several databases including PubMed, Google Scholar, Science Direct, and Directory of Open Access Journal (DOAJ), Spinger Link. Articles are collected for 1 month. The keywords for the search for the article were as follows: "Prenatal Stress" AND "Preterm Birth".

\section{Inclusion Criteria}

The articles included in this study are full paper articles with an observational study design. The articles are published in English and Indonesian. Selected articles discussed prenatal stress and preterm delivery outcomes. The intervention in the article was the perceived level of high stress during pregnancy. The analysis used was multivariate with adjusted odds ratio (aOR).

\section{Exclusion Criteria}

The articles published in this study are articles with a randomized controlled trial, protocol study, and pilot study design. The article is not published in English/ Indonesian. The statistical results reported are not aOR. Articles cannot be accessed or paid for. His article describes the condition of pregnant women with multiple pregnancies and other cormobids such as mental illness, major depression, heart disease, gestational hypertension, gestational dia 
betes, and other comorbid risk diseases during pregnancy.

\section{Operational Definition of variables}

The article search was carried out by considering the eligibility criteria defined using the PICO model. The population in this study were pregnant women $<37$ weeks' gestation with high prenatal stress intervention, comparison of low prenatal stress, and the outcome of preterm birth.

Prenatal stress is that pregnant women experience exposure to high levels of stress that can be caused by the influence of stressful life events or a difficult environment. The instrument used is a standardized stress measuring instrument with a continuous measuring scale.

Premature birth is the birth of a baby spontaneously or sectio caesarean surgery

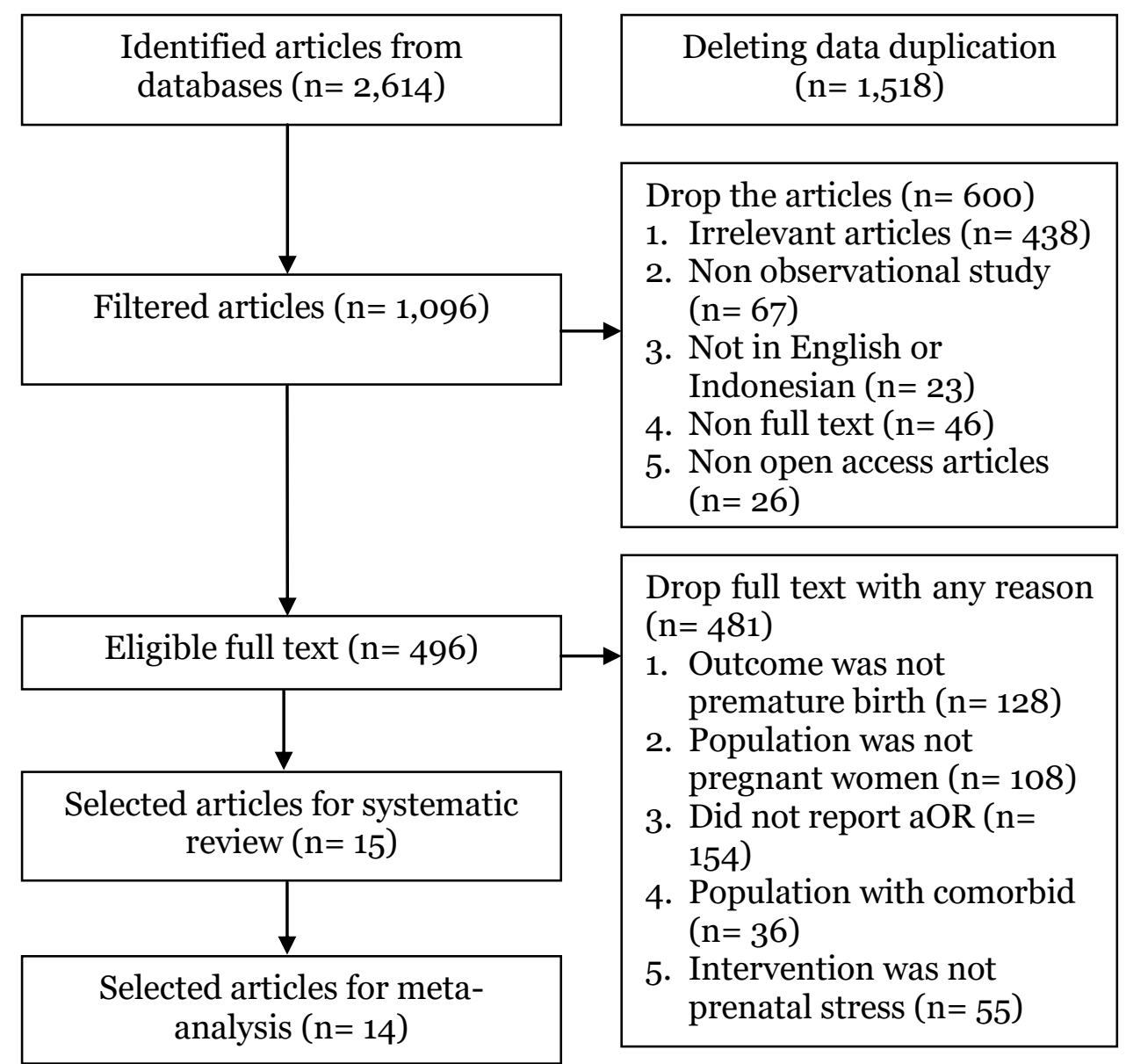

1. Irrelevant articles (n=

. Non observational study Non observational study $(n=67)$

Not in English or Indonesian $(\mathrm{n}=23)$

4. Non full text $(n=46)$

. Non open access articles $(\mathrm{n}=26)$

Drop full text with any reason $(n=481)$

Outcome was not Population was not pregnant women $(n=108)$

Did not report aOR $(\mathrm{n}=$ 154)

Population with comorbid

prenatal stress $(n=55)$ at gestational age $<37$ weeks from the calculation of the first day of last menstruation (HPHT). The instrument used was a mother register or count of the mother's HPHT with a continuous measuring scale.

\section{Data Analysis}

Data processing was carried out by a Review Manager (RevMan 5.3) by calculating the adjusted odds ratio and heterogeneity to determine which research models were combined and formed the final metaanalysis result.

\section{RESULTS}

The process of searching for articles through a database with journals can be seen in Figure 1.

Figure 1. PRISMA flow diagram 


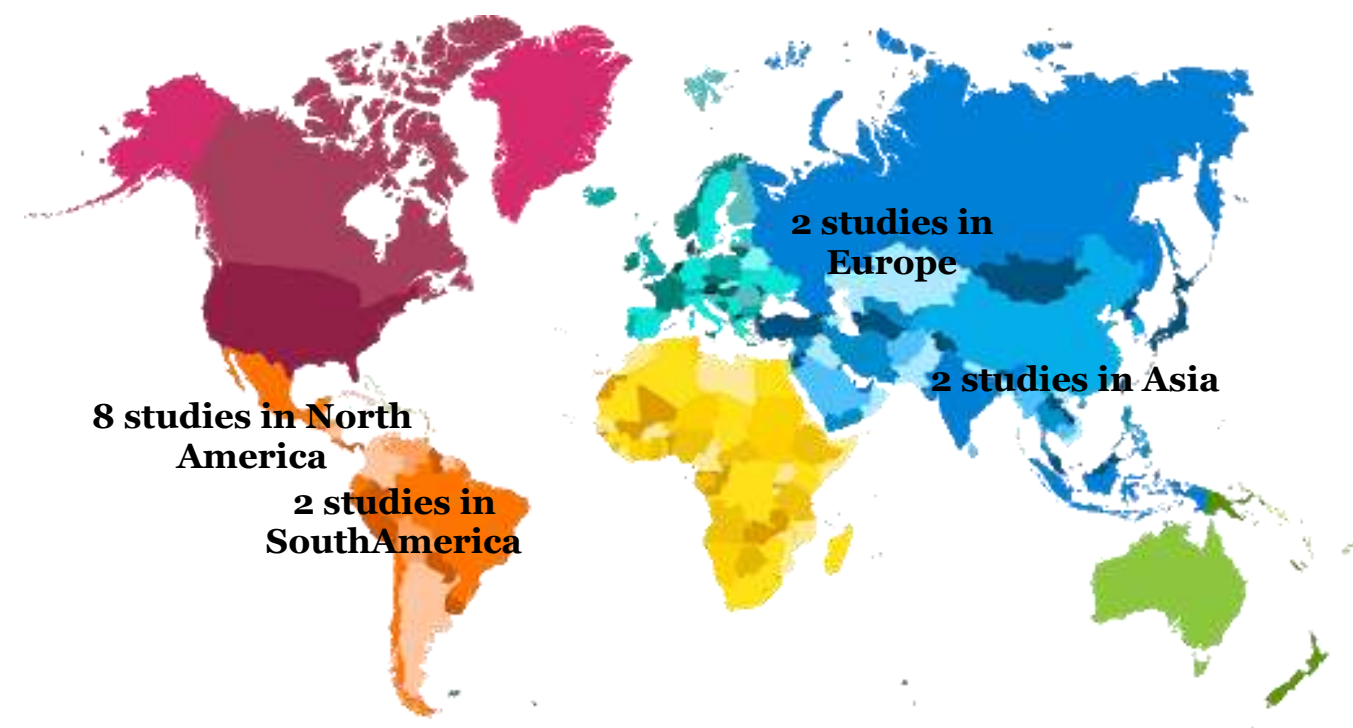

Figure 2. Map of the research area

The areas where articles were taken according to the inclusion criteria can be seen in Figure 2. Articles were obtained from 4 continents, namely North America, South America, Asia, and Europe.

Assessment of the quality of the study in this study was carried out using the following 12 questions for the Critical Appraisal Skills Program (CASP) for Cohort Study (CASP, 2018): 1) Does this study address a clearly focused problem ?; 2) Was the group included in an acceptable way?; 3) Is exposure measured accurately to minimize bias ?; 4) Are the results measured accurately to minimize bias ?; 5) Have the authors identified all the important confounding factors ?; 6) Was the follow-up to the subject of this study complete ?; 7) What are the results of this study ?; 8) How precise was the result ?; 9) Are the results reliable ?; 10) Can the results be applied to the local population ?; 11) Are the results of this study consistent with other available evidence ?; 12) What are the implications of this study for practice? Then each question is given a score with 1 for "yes" and o for "no". The results of the study quality assessment are shown in Table 1. And the 12 Critical Apparisal for Case Control Study questions (CEBM, 2005) are as follows: 1) Does this study address focused questions/ problems clearly ?; 2) Is the research method (study design) appropriate for answering research questions ?; 3) Are there enough subjects (employees, teams, divisions, organizations) in the study to establish that the findings did not occur by chance ?; 4) Is the selection of cases and controls based on external, objective and validated criteria ?; 5) Were the two groups comparable at the start of the study ?; 6) Are the outcome criteria objective and unbiased ?; 7) Is there data dredging ?; 8) Are objective and validated measurement methods used to measure results? If not, were the results scored by someone who did not know the group assignment (eg was the rater blind) ?; 9) Is the effect size practically relevant ?; 10) How precise is the estimated effect? Is the confidence interval granted ?; 11) Could there be confounding factors that have not been taken into account ?; 12) Can the results be applied to your organization? Then each question is given a score with 1 for "yes" and o for "no". The results of the study quality assessment are shown in Table 2. 
Table 1. Assessment of Research Quality using the Critical Appraisal Skills Program for Cohort Study

\begin{tabular}{|c|c|c|c|c|c|c|c|c|c|c|c|c|c|}
\hline \multirow{2}{*}{ Author (Year) } & \multicolumn{12}{|c|}{ Checklist of Questions } & \multirow{2}{*}{ Total } \\
\hline & $\mathbf{1}$ & 2 & 3 & 4 & 5 & 6 & 7 & 8 & 9 & 10 & 11 & 12 & \\
\hline Eick et al. (2020) & 1 & 1 & 1 & 1 & 0 & 1 & 1 & 1 & 1 & 0 & 1 & 1 & 10 \\
\hline Glynn et al. (2008) & 1 & 1 & 1 & 1 & O & 1 & 1 & 1 & 1 & 1 & 1 & 1 & 11 \\
\hline Gokoel et al. (2020) & 1 & 1 & 1 & 1 & 1 & O & 1 & 1 & 1 & $\mathrm{O}$ & 1 & 1 & 10 \\
\hline Grobman et al. (2018) & 1 & 1 & 1 & 1 & 1 & 0 & 1 & 1 & 1 & 1 & 1 & 1 & 11 \\
\hline Lau et al. (2013) & 1 & $\mathrm{O}$ & 1 & 1 & 1 & $\mathrm{O}$ & 1 & 1 & 1 & 1 & 1 & 1 & 10 \\
\hline Lukasse et al. (2013) & 1 & 1 & 1 & 1 & O & 1 & 1 & 1 & 1 & 1 & 1 & 1 & 11 \\
\hline Seravalli et al. (2014) & $\mathrm{O}$ & 1 & 1 & 1 & 1 & 1 & 1 & 1 & 1 & 1 & 1 & 1 & 11 \\
\hline Szegda et al. (2018) & 1 & 1 & 1 & 1 & $\mathrm{O}$ & 0 & 1 & 1 & 1 & O & 1 & 1 & 9 \\
\hline Vidal et al. (2014) & 1 & 1 & 1 & 1 & $\mathrm{O}$ & $\mathrm{O}$ & 1 & 1 & 1 & $\mathrm{O}$ & 1 & 1 & 9 \\
\hline Wainstock et al. (2014) & 1 & 1 & 1 & 1 & 1 & $\mathrm{O}$ & 1 & 1 & 1 & $\mathrm{O}$ & 1 & 1 & 10 \\
\hline
\end{tabular}

Table 2. Assessment of Research Quality using the Critical Appraisal for Case Control Study

\begin{tabular}{|c|c|c|c|c|c|c|c|c|c|c|c|c|c|}
\hline \multirow{2}{*}{ Author (Year) } & \multicolumn{12}{|c|}{ Checklist of Questions } & \multirow{2}{*}{ Total } \\
\hline & $\mathbf{1}$ & 2 & 3 & 4 & 5 & 6 & 7 & 8 & 9 & 10 & 11 & 12 & \\
\hline Christiaens et al (2020) & 1 & 1 & 1 & 1 & $\mathrm{O}$ & $\mathrm{O}$ & O & 1 & 1 & 1 & 1 & 1 & 9 \\
\hline Heaman et al (2008) & 1 & 1 & 1 & 1 & $\mathrm{O}$ & $\mathrm{O}$ & O & 1 & 1 & 1 & 1 & 1 & 9 \\
\hline Lillicreutz et al (2020) & 1 & 1 & 1 & 1 & $\mathrm{O}$ & $\mathrm{O}$ & $\mathrm{O}$ & 1 & 1 & 1 & 1 & 1 & 8 \\
\hline Sanchez et al (2018) & 1 & 1 & 1 & 1 & 1 & 0 & 0 & 1 & 1 & 1 & 1 & 1 & 10 \\
\hline
\end{tabular}

Table 3. Description of the primary study meta-analysis of the effect of prenatal stress on preterm birth

\begin{tabular}{|c|c|c|c|c|c|c|c|}
\hline $\begin{array}{l}\text { Author } \\
\text { (Year) }\end{array}$ & Country & $\begin{array}{c}\text { Study } \\
\text { Design }\end{array}$ & Sample & Population & Intervention & Control & Outcome \\
\hline $\begin{array}{l}\text { Eick et al. } \\
(2020)\end{array}$ & $\begin{array}{l}\text { Puerto } \\
\text { Rico }\end{array}$ & $\begin{array}{l}\text { Prospec- } \\
\text { tive } \\
\text { cohort }\end{array}$ & 1,047 & $\begin{array}{l}\text { Pregnant } \\
\text { women }<20 \\
\text { weeks }\end{array}$ & $\begin{array}{l}\text { Low-medium social support, per- } \\
\text { ceived medium-high stress*, } \\
\text { medium-high depression, percep- } \\
\text { tion of medium-high environment }\end{array}$ & $\begin{array}{l}\text { High social support, low stress } \\
\text { perception, low depression, low } \\
\text { environmental perception }\end{array}$ & $\begin{array}{l}\text { Premature } \\
\text { Birth }\end{array}$ \\
\hline $\begin{array}{l}\text { Glynn et } \\
\text { al. } \\
(2008)\end{array}$ & The USA & $\begin{array}{l}\text { Prospec- } \\
\text { tive } \\
\text { cohort }\end{array}$ & 415 & $\begin{array}{l}\text { Pregnant } \\
\text { women } 18-20 \\
\text { weeks and } 30- \\
32 \text { weeks }\end{array}$ & Prenatal stress * and anxiety & prenatal stress and low anxiety & $\begin{array}{l}(<37 \\
\text { weeks })\end{array}$ \\
\hline
\end{tabular}




\begin{tabular}{|c|c|c|c|c|}
\hline $\begin{array}{l}\text { Gokoel et } \\
\text { al } \\
(2020)\end{array}$ & Suriname & $\begin{array}{l}\text { Prospec- } \\
\text { tive } \\
\text { cohort }\end{array}$ & 1,143 & $\begin{array}{l}\text { Pregnant } \\
\text { mother }\end{array}$ \\
\hline $\begin{array}{l}\text { Grobman } \\
\text { et al } \\
(2018)\end{array}$ & The USA & $\begin{array}{l}\text { Prospec- } \\
\text { tive } \\
\text { cohort }\end{array}$ & 9,470 & $\begin{array}{l}\text { Women }<20 \\
\text { weeks } \\
\text { pregnant }\end{array}$ \\
\hline
\end{tabular}

Lau,

Macao

Prospec-

tive

cohort pregnant women
High mercury exposure (quartile 4), perceived high stress*, likelyhood of depression, age 16-19 and > 35 years, African and other ethnicities, parity $\leq 2$, urban and rural

Psychosocial measures include depression [EPDS], race [Krieger], perceived stress [PSS] *, anxiety [STAI-T], social support [MSS], resilience [CD-RISC], and cohort analysis of latent profiles associated with race and ethnicity [non-Black Hispanic, Hispanic, Asian, etc.]

2nd trimester Age $\leq 25$ years, single / divorced, low education level, non-Chinese,
not working, monthly income $>$ MOP \$ 10,000, residence size $>500 \mathrm{ft} 2$, rental housing, smoking habits before pregnancy, history of passive smoking before pregnancy, consumption habits alcohol,

passive smoking during pregnancy, first pregnancy, antenatal examinations performed $>$ first trimester, past obstetric complications, history of obstetric complications of current pregnancy, unwanted / planned pregnancy, poor medical history, high stress perception level $(\geq 24.5) *$, poor physical health $(<40.6)$, poor mental health (45.9)

Lukasse Norwey

Prospec- 40,077
17-30 weeks
Low mercury exposure (quartile 1), low stress perception, no depression, age 20-34 years, Asian ethnicity, parity $\geq 2$, rural

Psychosocial measures do not include depression [EPDS], race [Krieger], perceived stress [PSS], anxiety [STAI-T], social support [MSS], resilience [CD-RISC], and cohort from latent profile analyzes associated with with race and ethnicity [non-Black Hispanic, Hispanic, Asian, etc.]

Age $\geq 25$ years, married, higher education level, Chinese, work, monthly income <MOP \$10,000, residence size $<500 \mathrm{ft} 2$, private house, no smoking before pregnancy, no history of being passive smoking before pregnancy, no habit consumption of alcohol, not secondhand smoke during pregnancy, not first pregnancy, antenatal examinations performed during the first trimester, no history of past obstetric complications, no history of obstetric complications of current pregnancy, desired / planned pregnancy, good medical history, low stress perception level (<24.5), good physical health (> 40.6), good mental health (45.9)

Low emotional distress at 30 weeks
Premature Birth

\section{$(<37$} weeks)

Premature Birth 


\begin{tabular}{|c|c|c|c|c|}
\hline $\begin{array}{l}\text { et al } \\
(2014)\end{array}$ & & $\begin{array}{l}\text { tive } \\
\text { cohort }\end{array}$ & & $\begin{array}{l}\text { pregnant } \\
\text { women }\end{array}$ \\
\hline $\begin{array}{l}\text { Seravalli } \\
\text { et al } \\
(2014)\end{array}$ & $\begin{array}{l}\text { Philadel- } \\
\text { phia }\end{array}$ & $\begin{array}{l}\text { Prospec- } \\
\text { tive } \\
\text { cohort }\end{array}$ & 1,069 & $\begin{array}{l}\text { Pregnant } \\
\text { women } 16 \\
\text { weeks or } 20- \\
24 \text { weeks }\end{array}$ \\
\hline
\end{tabular}

\section{Szegda et Puerto}

al

(2018)
Prospec-
tive
cohort

$\begin{array}{ll}\text { Vidal et } & \text { Durham } \\ \text { al } & \\ \text { (2014) } & \\ \text { Wainstoc } & \text { Israel } \\ \text { k et al } & \\ \text { (2014) } & \end{array}$

\begin{tabular}{|c|c|c|c|c|}
\hline $\begin{array}{l}\text { Sanchez } \\
\text { et al } \\
(2013)\end{array}$ & Lima & $\begin{array}{l}\text { Case } \\
\text { Control }\end{array}$ & $\begin{array}{l}\text { Preterm= } \\
479 \\
\text { Aterm =4 }\end{array}$ & $\begin{array}{l}\text { Women }<20 \\
\text { weeks } \\
\text { pregnant }\end{array}$ \\
\hline
\end{tabular}

$\begin{array}{lll}\begin{array}{l}\text { Prospec- } \\ \text { tive }\end{array} & 537 & \begin{array}{l}\text { 12 weeks } \\ \text { pregnant } \\ \text { cohort }\end{array} \\ \begin{array}{l}\text { Prospec- } \\ \text { tive }\end{array} & 1,846 & \begin{array}{l}\text { Pregnant } \\ \text { mother }\end{array}\end{array}$

\section{weeks of gestation}

African-American, single marital status, low <high school education, smoker, history of miscarriage, BMI before pregnancy obesity, history of gestational hypertension, history of preterm birth, there is bacterial vaginosis during pregnancy, there is vaginal candidiasis, there is Chlamydia labor, high prenatal stress *

Stress at 12 weeks of gestation with a quartile stress score of $4\left(Q_{4}=>\right.$ 31 ), stress at 19-26 weeks of gestation with a stress score of 4 (Q4 => 30) * weeks, and > 26 weeks

cohort trchomatis, history of preterm
High * and low levels of stress during pregnancy

100-alarm * exposure stress status, age at delivery $\leq 20$ years and $>35$ years, originating from outside the territory of Israel, maternal parity> 2, unmarried marital status, hypertension

[PHQ-9] Mild (5-9) and moderatesevere $(\geq 10)$ depression, [DASS-21] Mild (10-13) and moderate-severe ( $\geq 14$ ) depression, [DASS-21] mild anxiety ( 8-9) and moderate-severe diabetes mellitus, gestational

\section{gestation}

Not African-American, non-marital single status, higher education > high school, non-smoker, no history of miscarriage, normal BMI before pregnancy, no history of gestational hypertension, no history of preterm birth, no bacterial vaginosis during pregnancy, none Vaginal candidiasis, no

Chlamydia trchomatis, no history of preterm labor, low prenatal stress

Stress at 12 weeks of gestation with a stress score of 1-3 quartiles $(\mathrm{Q} 1=$ $\leq 22, \mathrm{Q} 2=>22$ and $\leq 26, \mathrm{Q} 3=>26$ and $\leq 31$ ), stress at 19-26 weeks of gestation with a quartile score of 1$3\left(\mathrm{Q} 1=\leq 20, \mathrm{Q}_{2}=>20\right.$ and $\leq 25, \mathrm{Q} 3$ $=>25$ and $\leq 30$ )

Do not experience stress during pregnancy

Stress status not 100-alarm exposure, age at delivery 21-35 years, originating from the territory of Israel, maternal parity 1, marital status is married, no history of diabetes mellitus, no history of pregnancy hypertension

[PHQ-9] Minimal depression (o-4), Premature [DASS-21] Minimal depression (0- Birth 9), [DASS-21] minimal (o-7) and moderate-severe $(\geq 10)$ anxiety, [DASS- 21] minimal stress (o-14)

weeks)

Premature Birth

Premature Birth 
$(\geq 10)$, [DASS-21] mild stress (15$18)$ and moderate-severe $(\geq 19)$ *

Total stress [high stress *], Adverse Total stress [low stress], Adverse

Childhood Experience (ACE) score [high score $\geq 2$ ACEs], childhood and adult violence, depression during pregnancy

Miscarriage $\geq 2$ times, previous preterm birth, vaginal bleeding after 12 weeks, gestational hypertension, antenatal hospitalization, PROM, smoking during pregnancy, height $<155 \mathrm{~cm}$, physical abuse during pregnancy, age $<19$ years, low education, single marital status , moved 2 times in the past year, inadequate prenatal care, high stress perception, low self-esteem, low support, low weight gain $<9.1$ $\mathrm{Kg}$, anemia $\mathrm{Hb}<105 \mathrm{~g} / \mathrm{dL}$, weight gain range o-0.61 Kg / week, combination of non-Aboriginal race with violence during pregnancy and low support, combination of Aboriginal race with PROM; $<19$ years old; high stress perception *; single marital status; anemia

Stress during pregnancy*, premature contractions, tobacco use, history of previous preterm birth, genital tract infections

\begin{tabular}{|c|c|c|c|c|}
\hline $\begin{array}{l}\text { Christiae } \\
\text { ns et al } \\
\text { (2015) }\end{array}$ & Canada & $\begin{array}{l}\text { Case } \\
\text { Control }\end{array}$ & $\begin{array}{l}\text { Preterm= } \\
75 \\
\text { Aterm=1 } \\
48\end{array}$ & $\begin{array}{l}\text { Pregnant } \\
\text { mother }\end{array}$ \\
\hline $\begin{array}{l}\text { Heaman } \\
\text { et al. } \\
(2005)\end{array}$ & Manitoba & $\begin{array}{l}\text { Case } \\
\text { Control }\end{array}$ & $\begin{array}{l}\text { Preterm= } \\
226 \\
\text { Aterm=4 } \\
58\end{array}$ & $\begin{array}{l}\text { Pregnant } \\
\text { mother }\end{array}$ \\
\hline
\end{tabular}

(2016) 172

$\begin{array}{llll}\begin{array}{l}\text { Lillie- } \\ \text { creutz et }\end{array} & \text { Sweden } & \begin{array}{l}\text { Case } \\ \text { Control }\end{array} & \begin{array}{l}\text { Preterm }= \\ 168\end{array} \\ \text { al. } & & & \begin{array}{l}\text { Pregnant } \\ \text { mother }\end{array} \\ \text { Aterm }= & \\ & & & 172\end{array}$

\section{$(<37$}

Childhood Experience (ACE) score

[high score $\leq 2$ ACEs], no childhood and adult violence, no depression during pregnancy

Miscarriage $\leq 2$ times, no previous preterm birth, no vaginal bleeding after 12 weeks, no gestational

hypertension, no antenatal hospi-

talization, no PROM, no smoking during pregnancy, height $>155 \mathrm{~cm}$, no physical abuse during

pregnancy, age $>19$ years, higher education, married marital status, moved $<2$ times in the past year, adequate prenatal care, low stress perception, high self-esteem, high support, low weight gain $>9.1 \mathrm{Kg}$, anemia $\mathrm{Hb}>105 \mathrm{~g} / \mathrm{dL}$, weight gain range> $0.61 \mathrm{Kg} /$ week, no

combination of non-Aboriginal race with violence during pregnancy and low support, no combination of Aboriginal race with PROM; age> 19 years; low stress perception; married marital status; not anemia No stress during pregnancy, no premature contractions, no tobacco weeks) use, no previous history of preterm birth, no genital tract infection

Birth

\section{Premature}

*Variables entered in the meta-analysis 
Faujiah et al./ Meta-Analysis: Prenatal Stress on the Premature Birth

Table 3 shows that there are 10 cohort study articles and 4 case control study articles as evidence of the association of the effect of prenatal stress on preterm birth.

Figure 3 shows the forest plot results from the results of the sub-group analysis with the two study designs. The cohort study design showed that high prenatal stress could increase preterm birth by 1.35 times compared with low stress pregnant women, and it was statistically significant $(\mathrm{p}=0.02)$. The heterogeneity of the data shows $\mathrm{I}^{2}=60 \%$ so that the distribution of the data is heterogeneous (random effect model). Meanwhile, the case control study design showed that high prenatal stress could increase preterm birth twice compared to pregnant women who experienced low stress, and it was not statistically significant $(\mathrm{p}=0.25)$. The heterogeneity of the research data showed I $2=91 \%$ so that the distribution of the data was declared heterogeneous (random effect model).

The funnel plot shows a publication bias which is indicated by asymmetry of the right and left plots where 5 plots are on the right and 8 plots are on the left and 1 plot touches the line. The plot on the left of the graph appears to have a standard error between 0.3 and 0.5 and the plot on the right has a standard error between 0.1 and o.6. Bias also occurs from the imbalance between the distances between studies on both the right and left of the funnel plot. This is shown in Figure 4.

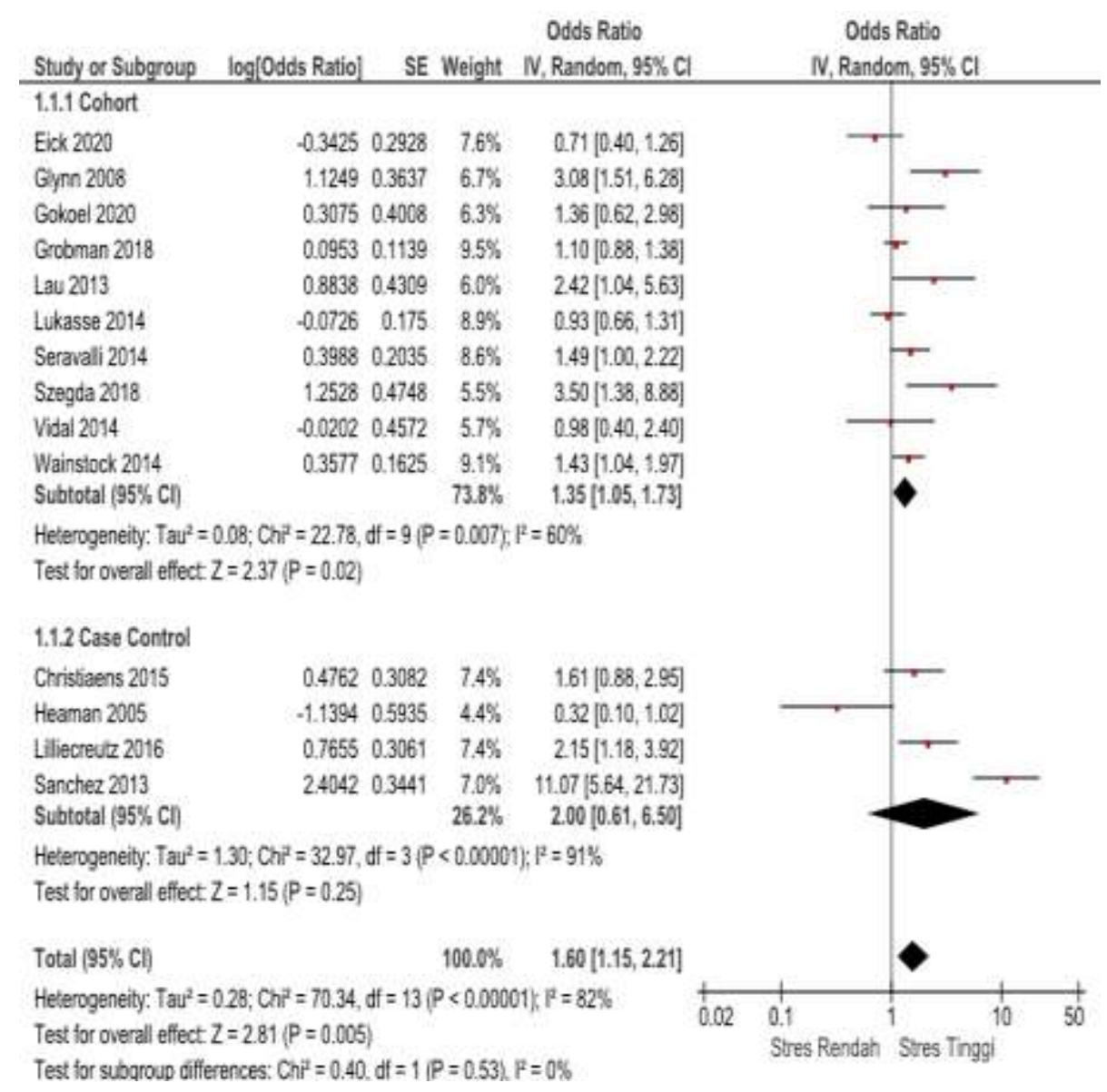

Figure 3. Forest plot meta-analysis of the effects of prenatal stress against preterm birth 


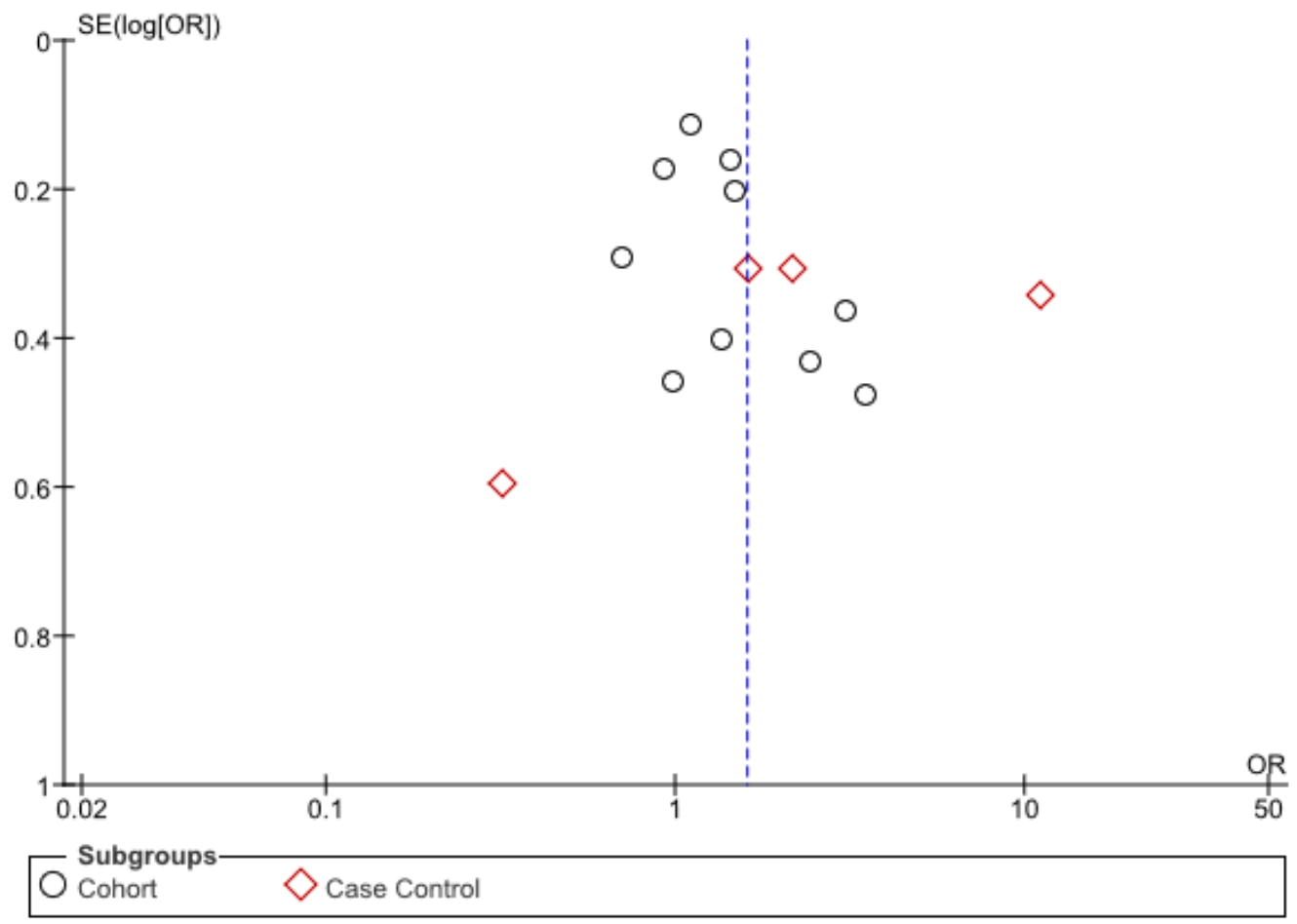

\section{Figure 4. Funnel plot of the meta-analysis of the effects of prenatal stress against preterm birth}

\section{DISCUSSION}

This systematic study and meta-analysis raises the theme of the effect of prenatal stress on preterm birth. The independent variable analyzed was prenatal stress or the perception of high levels of stress experienced during the pregnancy period. Studies that discusses data on preterm birth is considered important because of its scarcity but the incidence rate is a fairly high problem in the field of public health, especially maternal and child health. The number of relevant research published and accessible is still small and also has data excess problems (data duplication) (Murti, 2018). Most of the statistical results reported are in percentage or crude odds ratio (cOR), where the study did not control for confounding factors.

This systematic study and metaanalysis study was conducted using a study that controlled the confounding factor which can be seen from the study inclusion requirements, namely using multivariate analysis and the statistical results reported were adjusted odds ratio (aOR).

The combined estimate of the association of each risk factor with the incidence of preterm was processed using the RevMan 5.3 application with the generic inversevariance method. This method is used to analyze data in the form of rate (rate), timeto-event (time-to-event), hazard ratio, ordinal scale, adjusted estimate, average difference. - average (difference of mean) or ratio of average (ratio of mean).

The results of this systematic study and meta-analysis are presented in the form of a forest plot and a funnel plot. Forest plots show visually the amount of variation (heterogeneity) (Akobeng, 2005 in Murti, 2018). The funnel plot shows the relationship between the study effect size and the sample size of the various studies studied, which can be measured in a number of different ways (Murti, 2018). 
Faujiah et al./ Meta-Analysis: Prenatal Stress on the Premature Birth

\section{Prenatal stress on preterm birth}

The results of the forest plot research article with a cohort observational design showed that pregnant women who experienced stress had a 1.35 times risk of increasing preterm birth compared to pregnant women who did not experience stress and it was statistically significant. Meanwhile, a study article with a case-control observational design showed that pregnant women who experienced stress were twice as likely to increase preterm birth as pregnant women who did not experience stress and it was not statistically significant.

The large number of prospective studies with larger samples, suitable controls and standardized stress measures now available provide a basis for concluding that stress is a significant risk factor for preterm birth. The results of this study suggest that the relationship of stress with preterm birth appears to hold true for women of all nationalities, cultures and social classes with few exceptions. The resulting stress increases sexual risk behavior, decreases the use of prenatal care to detect infection, and decreases adherence to medication, thereby contributing to infection-related preterm labor. Stress is also associated with behaviors such as poor eating habits, smoking, and substance use that increase the risk of intrauterine growth retardation as a trigger for early labor. Thus, it can be concluded that women with lives characterized by high chronic stress tend to be less social. Stress support can become an important risk factor only in the absence of job support or support services, creating a more general risk factor for psychosocial vulnerability (Dunkel-Schetter, 1998).

This is in line with the study of Glynn et al (2008) which stated that pregnant women experiencing increased stress were three times more likely to have preterm delivery $(\mathrm{OR}=3.08,95 \% \mathrm{CI}=1.51-6.28, \mathrm{p}$
$<0.05)$. The pattern of changes in prenatal stress during pregnancy is an important predictor of preterm birth. The change in psychological stress response during pregnancy reflects that there is a change in the physiological environment of pregnant women.

There is growing empirical evidence based on the population of pregnant women from different ethnic, socioeconomic, and national backgrounds as a psychosocial factor that concludes that the relationship between high prenatal stress and shorter pregnancies is a more consistent set of findings. However, not all women report that high psychosocial stress can lead to preterm delivery, as some important questions remain about susceptibility to stress in pregnancy. These questions include issues regarding the nature of the stressful experience (including problems associated with assessing individual and community stress levels), the timing of stress before and / or during pregnancy, and the nature of the combined effects of stress (Wadhwa et al., 2001).

In addition, there are studies that state that pregnant women with high stress give birth to babies at gestational ages ranging from 24 to 41 weeks with an average of 39 weeks. Meanwhile, pregnant women without high stress give birth to babies with gestational ages ranging from 29 to 42 weeks with an average of 39 weeks. So it can be concluded that although stress is moderately correlated with preterm birth (correlation coefficient $=0.24, p<0.001$ ), it is not associated with the risk of preterm birth compared with low-stress pregnant women, after adjusting for maternal BMI, income, and high blood pressure $(\mathrm{OR}=1.10$, 95\% CI $=0.57-2.15, p=0.96$ ) (Vidal et al., 2014). 
Faujiah et al./ Meta-Analysis: Prenatal Stress on the Premature Birth

\section{AUTHOR CONTRIBUTION}

Irfa is the main researcher who selects the topic, explores and collects research data. Bhisma Murti and Hanung Prasetya played a role in analyzing data and reviewing research documents.

\section{CONFLICT OF INTEREST}

There is no conflict of interest in this study.

\section{FUNDING AND SPONSORSHIP}

This study is self-funded

\section{ACKNOWLEDGEMENT}

We are very grateful to the database providers PubMed, ScienceDirect, Google Scholar, Spinger Link, and Directory of Open Access Journal (DOAJ).

\section{REFERENCE}

Cardwell MS (2017). Stress: pregnancy considerations. Pediatr Emerg Care, 33 (12): 792-793. doi: 10.1097/o1.pec.oooo526609.89886.37.

Center for Evidence-Based Management. (2005). Critical appraisal of a survey appraisal questions. (10): 12. http://www.cebma.org/wp-content/uploads/Critical-Appraisal-Questions-for-aSurvey.pdf.

Critical Appraisal Skills Programme (2018). CASP checklist: cohort study. Casp Uk. www.casp-uk.net. on August 2020.

Dunkel-Schetter C (2004). Stress and preterm delivery. J Psychosom Obstet Gynaecol, 25(1): 1-2. doi: 10.1080/01674820410001737388.

Eick SM, Meeker JD, Swartzendruber A, McConnell RR, Brown P, Velez-Vega C, Shen Y, et al. (2020). Relationships between psychosocial factors during pregnancy and preterm birth in Puerto Rico. PLoS ONE, 15(1): 1-14. doi: 10.1371/journal.pone.0227976.
Glynn LM, Hobel CJ, Schetter CD, Sandman CA (2008). Pattern of perceived stress and anxiety in pregnancy predicts preterm birth. J Health Psychol, 27(1): 43-51. doi: 10.1037/0278-6133.27.1.43.

Gokoel AR, Zijlmans WCWR, Covert HH, Wahid FA, Shankar A, MacDonaldOttevanger MS, Hindori-Mohangoo $\mathrm{AD}$, et al. (2020). Influence of prenatal exposure to mercury, perceived stress, and depression on birth outcomes in suriname: Results from the mekitamara study. Int J Environ Res Public Health, 17(12): 1-14. doi: 10.3390/ijerph17124444.

Grobman WA, Parker CB, Willinger M, Wing DA, Silver RM, Wapner RJ, Simhan HN, et al. (2018). Racial disparities in adverse pregnancy outcomes and psychosocial stress. AOG, 131(2): 328-335. doi: 10.1097/AOG.ooooooooooo02441.

Khashan AS, Everard C, McCowan LME, Dekker, G, Moss-Morris R, Baker, PN, Poston L, et al. (2014). Second-trimester maternal distress increases the risk of small for gestational age. Psychol Med. 44(13): 2799-2810. doi: 10.1017/Soo33291714000300.

Murti B (2018).Prinsip dan Metode Riset Epidemiologi (Epidemiological Research Principles and Methods). 5th edn. Surakarta: Program Studi Ilmu Kesehatan Masyarakat, Program Pascasarjana, Universitas Sebelas Maret.

Shapiro GD, Fraser WD, Frasch MG, Seguin JR (2013). Psychosocial stress in pregnancy and preterm birth: Associations and mechanisms. J Perinat Med, 41(6): 631-645. doi: 10.1515/jpm-2012-0295.

Tanpradit K, Kaewkiattikun K (2020). The effect of perceived stress during pregnancy on preterm birth. Int $\mathrm{J}$ Wo- 
Faujiah et al./ Meta-Analysis: Prenatal Stress on the Premature Birth

men's Health. 12: 287-293. doi: 10.2147/IJWH.S239138.

Vidal AC, Neelon SEB, Liu Y, Tuli AM, Fuemmeler BF, Hoyo C, Murtha AP, et al. (2014). Maternal stress, preterm birth, and DNA methylation at imprint regulatory sequences in humans. Genet Epigenetics. 1(6): 37-44. doi: 10.4137/GEG.S18067.

Wadhwa P, Culhane JF, Rauh V, Barve SS, Hogan V, Sandman CA, Hobel CJ, et al. (2001). Stress, infection and preterm birth: a biobehavioural perspec- tive. Wiley Online Library. 15(2): 1729. doi: https://doi.org/10.1046/j.1365-3016.2001.00005.x.

Wainstock T, Shoham-Vardi I, Glasser S, Anteby E, Lerner-Geva L (2014). Fetal sex modifies effects of prenatal stress exposure and adverse birth outcomes', Stress. Informa Healthcare, 18(1): 49-56. doi: 10.3109/10253890.2014 .974153 . 